\title{
Vascular hypothesis of Alzheimer's disease: role of apoE and apoE receptors
}

\author{
Guojun Bu*, Chia-Chen Liu, Takahisa Kanekiyo \\ From Molecular Neurodegeneration: Basic biology and disease pathways \\ Cannes, France. 10-12 September 2013
}

\begin{abstract}
Background
Alzheimer's disease (AD) is a progressive neurodegenerative disease that has emerged as the most prevalent form of late-life dementia in humans [1]. Production of amyloid- $\beta$ (A $\beta)$ from the amyloid precursor protein (APP) and its subsequent accumulation, aggregation and deposition in the brain are central events in the pathogenesis of AD [1]. Cerebral amyloid angiopathy (CAA) is a major pathological feature of $\mathrm{AD}$ where amyloid spreads and deposits throughout the blood vessel walls in the central nervous system. These pathogenic events induce a specific clinical presentation profile including cerebral hemorrhage, stroke, ischemic infarctions, subarachnoid hemorrhage, seizures, cognitive impairment and dementia [2]. While $\mathrm{A} \beta$ is a key molecule in $\mathrm{AD}$, epidemiological studies have shown that several well-established risk factors for AD, including diabetes mellitus, atherosclerosis, stroke, hypertension, transient ischemic attacks, microvessel pathology and smoking, have a vascular component that reduces cerebral perfusion [3]. In fact, detection of regional cerebral hypoperfusion through neuroimaging techniques can preclinically identify individuals at risk for AD. Further, cerebral hypoperfusion precedes hypometabolism, cognitive decline, and neurodegeneration in AD [3]. Therefore, disturbance of cerebrovascular system is likely a major contributor to AD pathogenesis. Among the three human apolipoprotein E (apoE) isoforms (E2, E3 and E4), $A P O E 4$ is the strongest genetic risk factor for late-onset $\mathrm{AD}$. The most consistent finding that differentiates apoE4 from apoE3 is their respective roles in brain $A \beta$ clearance, where apoE4 is less efficient than apoE3 in promoting $A \beta$ clearance [4]. In addition, $A P O E 4$ also increases the risk for CAA and vascular dementia [4]. Because apoE4 is known to damage blood-brain barrier (BBB) integrity and reduces small cerebral vessels [5], apoE is likely involved in
\end{abstract}

the maintenance of cognitive function through regulating the function of cerebrovascular systems.

\section{Materials and methods}

We generated conditional knockout mice deleting a major apoE and $A \beta$ receptor LRP1 in vascular mural cells (smLRP1-KO), which include smooth muscle cells and pericytes. These mice were further bred to the background of amyloid model mice APP/ PS1. Cerebral blood flow, behaviors and $\mathrm{A} \beta$ metabolism were compared among human $A P O E$ isoform (E2, E3 and E4)-targeted replacement (TR) mice and between smLRP1-KO mice and wildtype littermate controls at young and old ages.

\section{Results}

We found that cerebral blood flow and memory performance are reduced, while endogenous $A \beta$ levels are elevated, in aged APOE4-TR mice compared to APOE3TR mice and in smLRP1-KO mice compared to controls. When crossed with APP/PS1 mice, deletion of LRP1 in vascular mural cells exacerbated $A \beta$ deposition both in the cortical parenchyma as amyloid plaques and along the cerebral vessels as CAA [6].

\section{Conclusions}

Our results demonstrate that the presence of APOE4 or an absence of apoE receptor LRP1 leads to cerebrovascular defects, which compromise $A \beta$ clearance machinery resulting in $A \beta$ accumulation in the brain. The resulting $A \beta$ aggregation and deposition further exacerbate cerebrovascular dysfunction in $\mathrm{AD}$.

\footnotetext{
Acknowledgements

This work was supported by grants from NIH, Alzheimer's Association, and BrightFocus Foundation.
} 


\section{References}

1. Selkoe DJ: Deciphering the genesis and fate of amyloid beta-protein yields novel therapies for Alzheimer disease. J Clin Invest 2002, 110:1375-1381.

2. Revesz T, Ghiso J, Lashley T, Plant G, Rostagno A, Frangione B, Holton JL: Cerebral amyloid angiopathies: a pathologic, biochemical, and genetic view. J Neuropathol Exp Neurol 2003, 62:885-898.

3. de la Torre JC: Alzheimer disease as a vascular disorder: nosological evidence. Stroke 2002, 33:1152-1162.

4. Liu CC, Kanekiyo T, Xu H, Bu G: Apolipoprotein E and Alzheimer disease: risk, mechanisms and therapy. Nat Rev Neurosci 2013, 9:106-118.

5. Bell RD, Winkler EA, Singh I, Sagare AP, Deane R, Wu Z, Holtzman DM, Betsholtz C, Armulik A, Sallstrom J, et al: Apolipoprotein E controls cerebrovascular integrity via cyclophilin A. Nature 2012, 485:512-516.

6. Kanekiyo T, Liu CC, Shinohara M, Li J, Bu G: LRP1 in brain vascular smooth muscle cells mediates local clearance of Alzheimer's amyloid-beta. J Neurosci 2012, 32:16458-16465.

doi:10.1186/1750-1326-8-S1-020

Cite this article as: Bu et al:: Vascular hypothesis of Alzheimer's disease: role of apoE and apoE receptors. Molecular Neurodegeneration 2013 8(Suppl 1):O20.

\section{Submit your next manuscript to BioMed Central and take full advantage of:}

- Convenient online submission

- Thorough peer review

- No space constraints or color figure charges

- Immediate publication on acceptance

- Inclusion in PubMed, CAS, Scopus and Google Scholar

- Research which is freely available for redistribution

Submit your manuscript at www.biomedcentral.com/submit 